\title{
A palavra da Faculdade
}

\section{FRANCIS HENRIK AUBERT}

A

FACULDADE DE FILOSOFIA, LETRAS E CIÊNCIAS hUMANAS DA USP, a despeito de sua existência relativamente curta - como curta é a história da institutição universitária brasileira - foi e é pródiga na geração de mitos. Mitos, não no sentido de ficção, de história de mentirinha bem contada, mas no sentido essencial do mito, como parâmetro, como referência para a nossa compreensão do mundo e do homem. E esses mitos são dos mais variados, cobrem as múltiplas áreas do conhecimento e do afeto. São mitos histórico-espaciais e arquitetônicos, como a Maria Antonia. São mitos pessoais vivos e ativos como Antonio Candido, Marilena Chauí, Aziz Ab'Saber, Aziz Simão, Alfredo Bosi, Bóris Schnaiderman. São mitos que já atingiram a transcendência e que, no entanto, ainda permanecem como arquétipos vivos na memória e na inspiração de muitos de nós, como Egon Schaden, Aroldo de Azevedo, Eurípedes Simões de Paula, Theodoro Henrique Maurer.

Hoje homenageamos um desses mitos, um mito que acaba de passar da condição de mito vivo, pulsante, dinâmico, imanente, para adicionar a seu percurso um novo papel, o de mito transcendente.

Qual a transcendência e a imanência particular de Florestan Fernandes? A sua lucidez? A sua honestidade intelectual a toda prova? A coerência imutável de suas conviç̧ões? A sua atuação política? Certamente todas essas facetas de sua rica personalidade são elementos essenciais da imagem que dele irradia. Mas, ainda que em uma combinação única, sui generis, muitos outros de nossos colegas presentes e passados, compartilham destas virtudes, são seus irmãos, companheiros e colegas em longos percursos de vida. Talvez o que mais se destaque, para nós, na figura de Florestan Fernandes e no legado que ele nos deixa é a sua preocupação com a questão social, com a dimensão social do conhecimento e com a necessidade não apenas de contemplar e de analisar, à distância, a complexa e dramática realidade social do Brasil, mas de engajar-se, de todos os modos, na superação de nossas misérias conjunturais e, principalmente, estruturais.

Quero crer que este legado, tão significativo para tantas pessoas, grupos e agremiações, tem um sentido todo especial para a Universidade: chama, conclamanos a pensar, a repensar e, em sendo o caso - e tenho certeza que seja o caso redirecionar algo mais marcadamente os nossos esforços, já marcantes na área da saúde e das tecnologias, ainda estão por ser adequadamente retomados na área 


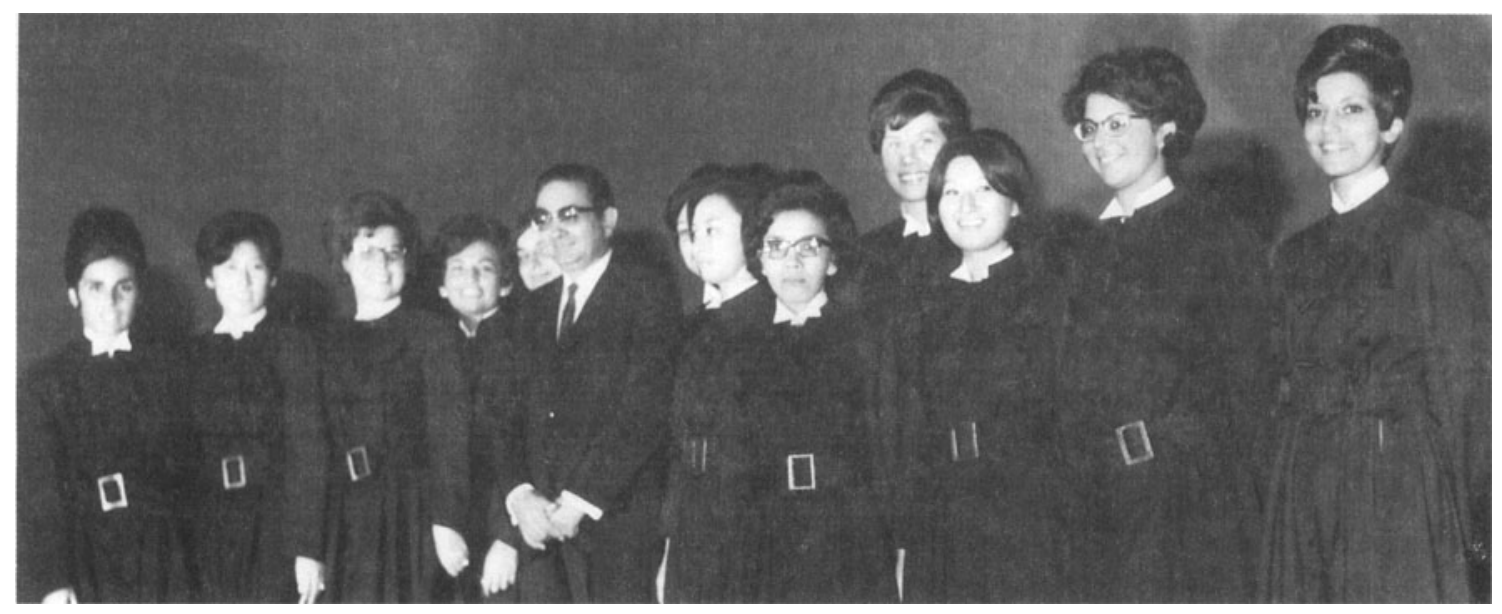

Em 1966, Florestan foi o paraninfo dos formandos do Departamento de Ciências Sociais da USP

da cultura e da educação. A FFLCH-USP, que teve, em sua origem, a dupla missão de pesquisar e estudar as realidades social, cultural e lingüística brasileiras e, concomitantemente, preparar os quadros do magistério do ensino público, acabou, por circunstâncias várias, relegando esta tarefa educacional a um segundo plano. Possa o exemplo de Florestan Fernandes, que por seu esforço pessoal, venceu todos os fatores condicionantes da miséria sócio-econômica e sócio-cultural, para que viesse a tornar-se um dos grandes pensadores nacionais, frutificar $\mathrm{em}$ nossas posturas, mais do que apenas em nossas estruturas, para que possamos gerar as condições necessárias que permitam a tantos outros potenciais Florestans passarem da potencialidade para a realidade. É essa uma das nossas principais responsabilidades, de nossos principais deveres e a figura/mito de Florestan está aí, para nos lembrar, permanentemente, das tarefas de que temos de nos desincumbir.

Francis Henrik Auberté vice-diretor da Faculdade de Filosofia, Letras e Ciências Humanas da USP.

Discurso feito pelo autor no Ato Presença de Florestan Fernandes, organizado pelo Instituto de Estudos Avançados na Sala do Conselho Universitário da USP em 5 de outubro de 1995. 